\title{
К 90-летию \\ ОЛЕГА ВИКТОРОВИЧА МЕДВЕДЕВА
}

\section{(c) 2021 г. Ольга Викторовна Кузнецова ${ }^{1}$}

${ }^{1}$ Старший научный сотрудник, Институт археологии им. А.Х. Маргулана, г. Алматы, Казахстан. E-mail: olga_kuznetsova@mail.ru

Аннотация. В январе 2021 г. отметил свой 90-летний юбилей Олег Викторович Медведев - старейший сотрудник Института археологии им. А. Х. Маргулана. На протяжении многих лет Олег Викторович работал фотографом в Институте. Благодаря его кропотливой работе были зафиксированы многочисленные раскопки, которые проводили археологи.

Ключевые слова: археология, О.В. Медведев, фотография, фотофиксация

\section{ОЛЕГ ВИКТОРОВИЧ МЕДВЕДЕВТІН 90 жылдығына арналады}

\section{Ольга Викторовна Кузнецова ${ }^{1}$}

${ }^{1}$ аға ғылыми қызметкер, Ә.Х. Марғұлан атындағы Археология институты, Алматы қ., Қазақстан. E-mail: olga_kuznetsova@mail.ru

Аннотация. 2021 жылғы қаңтарда Ә.Х. Марғұлан атындағы Археология институтының ең қарт қызметкері Олег Викторович Медведев өзінің 90 жасқа толуын атап өтті. Олег Викторович көптеген жылдар бойы институтта фотограф болып жұмыс істеді. Оның қажырлы еңбегінің арқасында археологтар жүргізген көптеген қазбалар суретке түсірілді.

Түйін сөздер: археология, О.В. Медведев, фотография, фототүсіру

\section{To the 90th anniversary of OLEG V. MEDVEDEV \\ Olga V. Kuznetsova ${ }^{1}$ \\ ${ }^{1}$ Senior Researcher, A.Kh. Margulan Archeology Institute, Almaty, Kazakhstan. E-mail: olga_kuznetsova@mail.ru}

Abstract. In January 2021, Oleg V. Medvedev, the oldest employee of the A. Kh. Margulan Archeology Institute, celebrated his 90th anniversary. For many years, Oleg V. Medvedev worked as a photographer at the Institute. Thanks to his diligent work, numerous excavations conducted by archaeologists were recorded.

Keywords: archaeology, O.V. Medvedev, photography, photo recording

Олег Викторович Медведев родился 21 января 1931 года в с. Москалево Охинского района Сахалинской области. В 1949 г. Олег Викторович окончил 8 классов средней школы и поступил на работу на завод «Казсельэлектро». В 1951-1954 гг. служил в рядах Советской армии в качестве фотографа воинской части. В 19551959 гг. работал в типографии № 4 и одновременно принимал участие в работе археологических экспедиций Института истории, археологии и этнографии АН КазССР в качестве внештатного фотографа. В 1960 г. Медведев О. В. был зачислен в штат отдела археологии на должность старшего лаборанта-фотографа, а в 1969 г. переведен на должность инженерафотографа. 
В 1960-1970-е гг. О. В. Медведев в качестве фотографа принимал участие в успешном и качественном выполнении в срок научноисследовательских планов Института истории, археологии и этнографии АН КазССР, а также в издании документальных сборников: «Казахстан в период Великой Отечественной войны (1941-1945 гг.)», том 1; «Иностранная военная интервенция и гражданская война в Средней Азии и Казахстане», том 2; книг «Казахская народная одежда», «Древняя культура племен Центрального Казахстана», «Подъем культурно-технического уровня рабочих угольной промышленности Казахстана», «Социальноэкономические преобразования в ауле и деревне Казахстана» и др.

С самых первых лет работы в отделе археологии О. В. Медведев участвовал в полевых исследованиях и, прежде всего, - Южно-Казахстанской комплексной археологической экспедиции (ЮККАЭ), где, благодаря его ответственному и творческому подходу к сложному искусству фотофиксации археологических объектов, была проведена съемка обширных площадей раскопок городища Отрар и Отрарского оазиса, монет из Отрара, репродукция чертежей.

Благодаря его работам с высокой степенью достоверности были зафиксированы такие уникальные археологические объекты, как курган «Иссык» с «золотым» человеком и другие памятники Семиречья и юга Казахстана; была осуществлена репродукция иллюстративного материала к монографии А. Х. Маргулана «Бегазы-дандыбаевская культура Центрального Казахстана» и для пятитомника «История Казахской ССР».

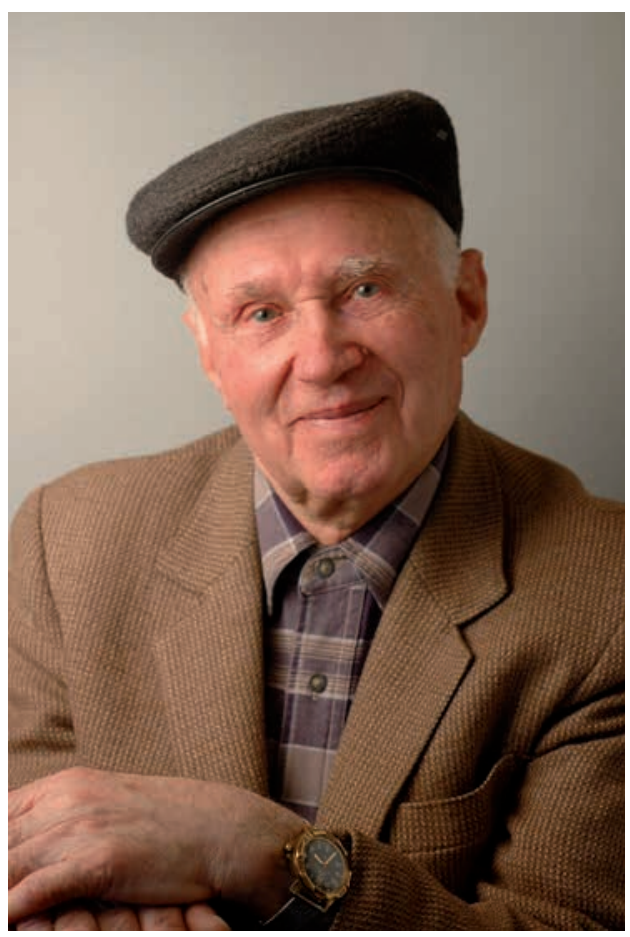

Рис. 1. Олег Викторович Медведев. 2006 г. Фото О.В. Белялова

Fig. 1. Oleg V. Medvedev. 2006. Photo by O.V. Belyalov

В 1973 г. Олег Викторович принимал активное участие в оформлении первого в Казахстане специализированного Музея археологии: им проводилась съемка музейных экспонатов - орудий труда из камня эпохи палеолита, керамических сосудов, изделий из дерева, бронзы, серебра, золота. Его фотографии стали основой первого каталога Музея археологии.

Олег Викторович освоил и успешно применял на практике новые приемы фото- и киносъемки археологических памятников в полевых и лабораторных условиях. Так, в 1963 г. О. В. Медведев принимал участие в создании любительского фильма об археологических раскопках в Семиречье. 


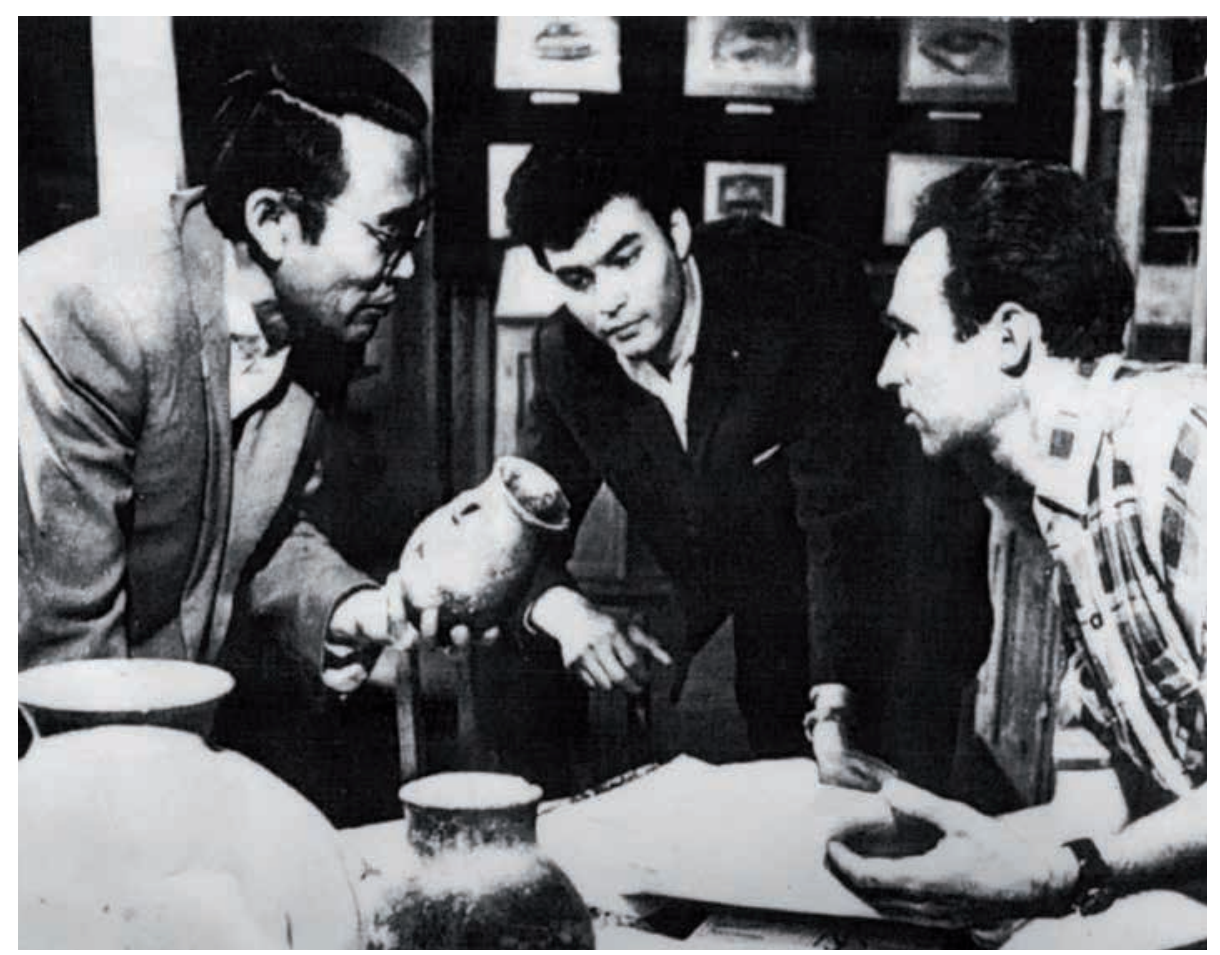

Рис. 2. Подготовка экспозищии Музея археологии. 1973 г. Слева направо: К.А. Акишев, К.М. Байпаков, О.В. Медведев

Fig. 2. Preparation of the exposition of the Museum of Archaeology. 1973. From left to right: K.A. Akishev, K.M. Baipakov, O.V. Medvedev

Он принимал активное участие в общественной жизни Института являлся фотокорреспондентом институтской газеты «Историк». Благодаря его неутомимой и незаметной работе были запечатлены моменты жизни археологов, их полевого быта и трудной работы.

Многие годы Олег Викторович занимался каталогизацией фотопленок, созданием аналогового фотоархива ЮККАЭ, где активно работал с начала раскопок городища Отрар и памятников Отрарского оазиса с 1969 по 2010 гг.
Трудно представить, сколько километров фотопленки было отснято и проявлено юбиляром за его более чем полувековую работу в качестве фотографа археологических экспедиций, сколько дорог в полевых разведках было пройдено, сколько заснято раскопов и находок.

Сейчас Олег Викторович Медведев находится на заслуженном отдыхе. В год Юбилея желаем ему здоровья и долгих лет жизни.

Мақала туралы ақпарат / Информация о статье / Information about the article. Редакцияға түсті / Поступила в редакцию / Entered the editorial office: 21.01.2021. 